Egypt. J. of Nutrition and Health Vol. 15 No. 1 January (2020)

\title{
The Protective Effect of Seeds and Sprouts of Fenugreek and Alfalfa on Rats Exposed to Lead Poisoning
}

\author{
Rasha M. Bahnasy,Eman El-SayedAbd-Elhady \\ and Mai Hussein Abd- Elfatah \\ ${ }^{1}$ Nutrition and Food Science Dept. Faculty of Home Economics \\ Al- Azhar University
}

\begin{abstract}
This study was conducted on rats to investigate the effectiveness of Fenugreek seeds, Fenugreek sprouts, Alfalfa seeds and Alfalfa sprouts as nutraceuticals for hepatointoxication induced

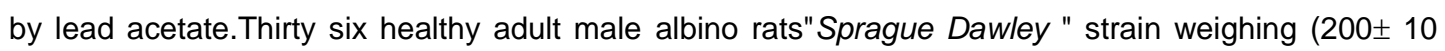
gm.), were used and divided into 6 equal groups, one was kept as a (-ve) control group, while the other groups received daily $0.4 \%$ lead acetate in distilled water to induce hepatotoxicity. Four groups were given the experimental seeds and their sprouts in the form of powder mixed with the basal diet (Fenugreek seeds $5 \%$, Fenugreek sprouts5\%, Alfalfa seeds $2 \%$ and Alfalfa sprouts $2 \%$ ) respectively for eight weeks. The sixth group of rats were kept as (+ve)control group received basal diet only. At the end of the experiment, feed intake (FI), body weight gain (BWG), feed efficiency ratio(FER) and relative weights of liver, kidneys, heart, spleen were calculated. Also, Liver enzymes (AST, ALT\& ALP), serum total protein, albumin\& globulin and MAO were also determined in serum, lead was determined in whole blood, antioxidant enzymes (SOD \& $\alpha$-GST) were determined in the liver tissue. The results indicated that rats that received lead acetate and fed on basal diet only recorded significant changes for all above biological and biochemical parameters. While the treatment with seeds and their sprouts revealed significant improvement in all liver function biochemical parameters and antioxidant enzymes. The study concluded that; seeds of Fenugreek and Alfalfa and their sprouts were effective in improving liver dysfunction and other side effects. This may be attributed to the high content of phenolic compounds in these seeds.
\end{abstract}

Key word: Hepatotoxicity - liver enzyme - lead acetate - Fenugreek seeds - Alfalfa seeds Antioxidant enzymes

\section{Introduction}

The environmental contamination by heavy metals has increased drastically along with the rapid development of modern industry. Among these metals is lead, of which its levels have increased substantially during the last few years (Bilandžić et al., 2009). Lead (Pb) a soft, grey-blue heavy metal is a common cause of poisoning of domestic animals throughout the world(Khan et al., 2008) .Workers were exposed to lead in several ways daily.e.g. those work in gasoline additives, food can soldering, lead based paints, ceramic glazes, drinking water systems and folk remedies(Markowitz 2000). Health hazards from increased leadexposure was found to produce wide range of biochemical and physiological dysfunctions (Courtois et al., 2003). 


\section{Rasha M. Bahnasy, et al}

Liver is the largest gland inside the body and some other animals; it lies below the diaphragm in the abdominal-pelvic region of the abdomen, where it performs a wide range of metabolic activities necessary for homeostasis, nutrition and immune defense (Ezejindu et al., 2013).Also, it has many functions including making bile, changing food into energy, cleaning poisons from the blood, etc. (Mahan and Escott-Stump, 2008).Most of the toxic compounds in the body are metabolized in liver. The entry of these toxicants into the body is principally via the gastrointestinal tract, and after absorption, they are transported through the hepatic vein to the liver(Doherty, 2000). Liver plays a major role in lead metabolism, and it is in special risk due to the oxidative action of this xenobiotic as there was unquestionable evidence that lead induced lipid peroxidation of hepatic cellular membranes (Sivaprasad et al., 2004).

Herbs have been used in all parts of the world not only as food but also as potent drugs for thousands of years. They do not work like chemical drugs and they are not substitute of them (Vuorela et al., 2004; Horne, 2013). Medicinal plants are used by $80 \%$ of the world population especially in developing countries to cure and improve the general health, principally due to the common belief that plant-derived drugs are without any side effects along with being economical and locally accessible (Gupta and Raina, 1998).

Fenugreek (Trigonellafoenum-graecumL) is a member of the leguminous family (Board, 2010) which is an annual plant found primarily in Mediterranean countries, the Middle East, and India. Fenugreek is an important spice and its dried seeds have wide application in food and beverages. Fenugreek has been reported to be an important medicinal plant with a large number of medicinal properties such as restorative and nutritive properties (appetite stimulant) with hypocholesterolemic, antidiabetic, antileukemic and antimicrobial effects (Acharya et al., 2008; Murlidhar and Goswami, 2012). The chemical composition of fenugreek seed (FS) has been thoroughly studied and its medicinal properties are associated with its phytochemicals such as galactomannans, phenolic compounds, alkaloids, proteins, vitamins (A precursors B1, C and nicotinic acid) and volatile oils(Acharyaet al., 2008). Germinated fenugreek seeds rich in bioactive antioxidant substances are also used extensively as an important ingredient in daily food preparations and herbal formulations(Khole et al., 2014).

Alfalfa and called Medicago sativa L. (the genus Medicago), belonging to the family of legume (Fabaceae), known as "the king of forage", is cultivated as a perennial forage crop in temperate zones worldwide (Ma et al., 2016). M. sativa is consumed as a vegetable in the form of salads, tortillas, croquettes, puddings, soups and casseroles all over the world (Martínez et al., 2016). As a functional food, it is mentioned in many ancient medical books in China, such as the Compendium of Materia Medica, and was regarded as the alfac-facah (the father of all food) by the ancients (Ehsanpour and Razavizadeh, 2005)In the form of crops and vegetables, M. sativa contains abundant nutrients with potential health-promoting effects, including antioxidant, anti-inflammatory, anticancer, antibacterial, anxiolytic, immunomodulatory and memory-improving activities, etc(Bora and Sharma, 2011; Chen et al., 2015; Rafińska et al., 2017).Extensive phytochemical studies of $M$. sativa have led to the isolation of a number of flavonoids, saponins, alkaloids, coumarins, fatty acids and essential oils, with the flavonoids being the chemical constituents(Abbruscato et al., 2014; Rafińska et al., 2017). Because of the excellent quality of the nutritional components and various biological activities in $M$. sativa, it has been approved by the European Food Safety Authority as a kind of dietary supplement(Gatouillat et al., 2014). 


\section{Egypt. J. of Nutrition and Health Vol. 15 No. 1 January (2020)}

\section{Materials and Methods}

Materials :

Alfalfa seeds and Fenugreek seeds were obtained fromThe Agriculture Seeds, Herbs and Medicinal Plants Company, Cairo, Egypt. Lead acetate, casein (85\%), vitamins mixture and salt mixture were obtained from El- Gomhoryia Company for Chemical Industries, Cairo, Egypt. Barn, corn starch and corn oil purchase from local market. Thirty-six adult male albino rats of "Sprague Dawley" Strain was obtained from the laboratory animal colony. Ministry of Health and Population, Helwan, Cairo, Egypt.

\section{Methods :}

Alfalfa seeds and Fenugreek seeds were cleaned manually to remove broken seeds, dust and other extraneous materials and then drained and washed with Purified water. All seeds were dried under shade at room temperature then grinded using a blender into fine powder and were kept in dark glass containers in a refrigerator till use. To prepare the sprouts seeds were washed with purified water and then soaked in purified water for $12 \mathrm{~h}$ at ambient temperature. A seed to water ratio of 1:10 (W/V) was used. The unimbibed water was discarded. The soaked seeds were rinsed twice in water.The soaked seeds were allowed to germinate under a wet muslin cloth for $2: 4$ day with or without light at $37^{\circ} \mathrm{C}$ and $99 \%$ relative humidity, with frequent watering as described by(Obizoba and Atii, 1994). The sprouts were rinsed in purified water and dried by dry air at room temperature then grinded using a blender into fine powder and were kept in dark glass containers in a refrigerator till use.

\section{Biological experiment}

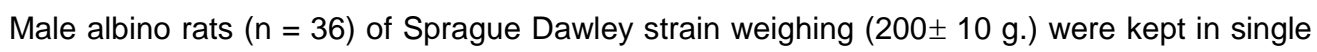
well aerated wire cages with wire bottoms under hygienic conditions and fed on basal diet for one week for adaptation. The diet was introduced to the rats in special food containers to avoid scattering of food. In addition, water was provided to the rats by glass tube projection through the wire cages. Food and water were provided ad-libitum and checked daily.

After adaptation for one week, the rats were divided into six groups (6 ratseach) as follow : group (1) were fed on basal diet ( as a negative control group ). From group two to group six,rats received $0.4 \%$ lead acetate in distilled water (Sivaprasad et al., 2004) . group (2) were fed on basal diet (as a positive control group).Group (3) were fed on basal diet supplemented with 5\%Fenugreek seeds. Group (4) were fed on basal diet supplemented with $5 \%$ Fenugreek sprouts. Group (5) were fed basal diet supplemented with $2 \%$ Alfalfa seeds. Group (6) were fed basal diet supplemented with $2 \%$ Alfalfa sprouts, added on the expense of corn starch.

The experimental period lasted for 8 weeks. At the end of the experimental period, rats were fasted overnight before sacrificed and blood samples were collected from each rat and centrifuged to obtain the serum. Serum was carefully separated and transferred into dry clean Eppendorf tubes and kept frozen at- $20^{\circ} \mathrm{C}$ for analysis as described by (Schermer, 1967). Liver,kidneys, spleen and heart were removed from each rat by careful dissection, cleaned from the adhesive matter by a saline solution( $0.9 \%$ ), dried by filter paper and weighed.At the end of the experiment, feed intake, body weight gain, organs weight as a percent of total body weight and Feed Efficiency Ratio were determined. According to (Chapman et al., 1959). 


\section{Rasha M. Bahnasy, et al}

ASTand ALTwere determined in the serum according to the method described by (Reitman and Frankel, 1957). Serum alkaline phosphatase determination was performed according to the colorimetric method of(Roy, 1970).Protein was estimated by Biuret reaction in which peptide bonds of protein react with alkaline copper solution to give a violet coloration as described by (Sonnenwirth and Jarett, 1980).Albumin was determined according to the method described by(Drupt, 1974)and modified by,(Spencer and Price, 1977).Serum globulin was calculated according to(Chary and Sharma, 2004).Lead is determined according to the method described by(Villeda-Hernandez et al., 2001).Monoamine oxidase (MAO) was determined according to(Holt et al., 1997).

After rats being sacrificed,the liver was excised immediately for biochemical investigation. Each sample was washed in saline solution, dried by filter paper and weighed then,was placed in a dry clean aluminum foil and kept frozen till estimated antioxidant enzymes levels. Superoxide dismutase (SOD) activity was determined in liver tissue according to(Misra and Fridovich, 1972). $\alpha$-glutathion Stransferases was determined in liver tissue according to (Habig et al., 1974).

Statistical analysis was carried out using the programme of Statistical Package for the Social Sciences (SPSS), PC statistical software (Version 20; Untitled-SPSS Data Editor).The results were expressed as mean \pm standard deviation (mean $\pm \mathrm{SD}$ ). Data were analyzed using one-way classification, analysis of variance (ANOVA). (Snedecor and Cochran, 1979).

\section{Results and discussion}

Effect of Fenugreek and Alfalfa seeds on body weight gain, feed intake and feed efficiency ratio.

As shown in table (1)feed intake (FI) recorded significant decrease of $(+v e)$ control group $(15.20 \pm 1.09)$ when compared to (-ve) control group (18.2 \pm 1.3$)$. Rats received diet supplemented with fenugreek seeds $(5 \%)$, fenugreek sprouts $(5 \%)$, alfalfa seeds $(2 \%)$ and alfalfa sprouts $(2 \%)$ showed significant increases $(\mathrm{P}<0.05)$ in $\mathrm{FI}$ when compared with $(+\mathrm{ve})$ control group. All of them recorded no significant difference with the (-ve) control group. The best results were recorded by alfalfa seeds $(2 \%)$ group which was the nearest value to $(-\mathrm{ve})$ control group $(17.80 \pm 0.44) \&(18.2 \pm 1.3)$ respectively.

Results for body weight gain (BWG) recorded significant decrease of (+ve) control group (27.54 \pm 3.85$)$ when compared to (-ve) control group (37.7 \pm 6.84$)$. Rats that received diet supplemented with fenugreek seeds $(5 \%)$ and fenugreek sprouts $(5 \%)$ showed no significant difference $(\mathrm{P}<0.05)$ in BWG when compared with the (+ve) control group but the other which received diet supplemented with alfalfa seeds $(2 \%)$ and alfalfa sprouts $(2 \%)$ showed significant increases $(P<0.05)$ in BWG compared to (+ve) control group. The best results were recorded by alfalfa sprouts $(2 \%)$ group which was the nearest value to $(-\mathrm{ve})$ control group $(35.42 \pm 4.41) \&(37.72 \pm 6.84)$ respectively.

Feed efficiency ratio (FER) recorded non-significant difference of the (+ve) control group when compared with the (-ve) control group. Rats that received diet supplemented with fenugreek sprouts $(5 \%)$ and alfalfa sprouts $(2 \%)$ showed significant decreases $(P<0.05)$ in FER when compared with the (-ve) control group, the best result was recorded by the group that fed on alfalfa (2\%) which was the nearest value to the (-ve) control group.

These findings are in agreement with (Ibrahim et al., 2011) who found that lead caused decreases in rats' growth rate when fed on it. Also, agreed with(Seddik et al., 2010) who reported that chronic $\mathrm{Pb}$ exposure for 90 days was associated with a decrease in body weight gains when compared 


\section{Egypt. J. of Nutrition and Health Vol. 15 No. 1 January (2020)}

to control rats. (El-Nekeety et al., 2009) indicated that animals treated with lead acetate( LA) showed a significant decrease in feed intake and consequently the body weight gain. The loss in body weight may be caused by the toxic ions associated with other factors, causing imbalance in metabolism produced by impairing zinc-dependent enzymes which are necessary for many metabolic processes.(Hwang and Wang, 2001).

Also, it is known that $\mathrm{Pb}$ induced growth depression duo to reduced food consumption through the contact of lead with appetite-depressant receptors in the gastrointestinal tract (Sharifi et al., 2002). Some studies indicated that fenugreek seed extract supplementation may reduce the body and adipose tissue weight (Chevassus et al., 2010; Geetha et al., 2011). The probable mechanism may be that fenugreek flushes out the carbohydrates from the body before they enter the blood stream resulting in weight loss. Also, fenugreek seeds contain a high proportion (40\%) of soluble fiber. This fiber forms a gelatinous structure (similar to guar gum) which may have effects on slowing the digestion and absorption of food from the intestine and creates a sense of fullness in the abdomen, thus suppresses appetite and promotes weight loss(Geetha et al., 2011). (Raju et al., 2001) showed that Trigonella seed powder treatment caused a significant and consistent weight gain over the period of administration.

Table (1):

Effect of Fenugreek and Alfalfa seeds on body weight gain, feed intake and feed efficiency ratio in hepatic intoxicated rats.

\begin{tabular}{l|c|c|c}
\hline Groups & Parameters & BWG & FER \\
\hline (-ve ) Control & $18.2^{\mathrm{a}} \pm 1.3$ & $37.72^{\mathrm{a}} \pm 6.84$ & $0.103^{\mathrm{a}} \pm 0.0024$ \\
\hline (+ve ) Control & $15.2^{\mathrm{b}} \pm 1.09$ & $27.54^{\mathrm{d}} \pm 3.85$ & $0.073^{\mathrm{abc}} \pm 0.0033$ \\
\hline Fenugreek seeds 5\% & $17.40^{\mathrm{a}} \pm 0.89$ & $29.09^{\mathrm{bcd}} \pm 4.63$ & $0.078^{\mathrm{abc}} \pm 0.013$ \\
\hline Fenugreek sprouts5\%. & $17.20^{\mathrm{a}} \pm 0.38$ & $28.05^{\mathrm{cd}} \pm 0.79$ & $0.052^{\mathrm{c}} \pm 0.028$ \\
\hline Alfalfa seeds 2\%. & $17.80^{\mathrm{a}} \pm 0.44$ & $34.64^{\mathrm{abc}} \pm 6.37$ & $0.094^{\mathrm{ab}} \pm 0.019$ \\
\hline Alfalfa sprouts 2\% & $17.60^{\mathrm{a}} \pm 0.89$ & $35.42^{\mathrm{ab}} \pm 4.41$ & $0.062^{\mathrm{bc}} \pm 0.029$ \\
\hline \multicolumn{2}{l|}{ Different superscript letters in the column denote high significant differences $(\mathrm{P}<0.05)$. gm during the whole period. }
\end{tabular}

\section{Effect of Fenugreek and Alfalfa seeds on relative organs weight.}

As shown in table (2) relative organs weight values showed significant increase in(+ve) control group as compared with (-ve) control group. Rats that received diets supplemented with fenugreek seeds $(5 \%)$, fenugreek sprouts $(5 \%)$,alfalfa seeds $(2 \%)$ and alfalfa sprouts $(2 \%)$ showed significant decrease $(\mathrm{P}<0.05)$ in relative liver weight when compared with $(+v e)$ control group. The best results

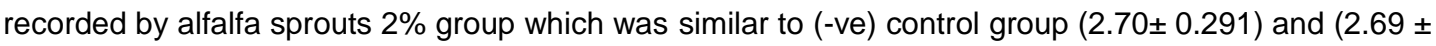
0.311 ) respectively.

Rats that received diets supplemented with fenugreek seeds (5\%), fenugreek sprouts (5\%) and alfalfa sprouts $(2 \%)$ showed significant decrease $(\mathrm{P}<0.05)$ in relative heart weight when compared with (+ve) control group. but there was no-significant decrease $(P<0.05)$ in Alfalfa seeds $(2 \%)$ when compared with (+ve) control group. The best result was recorded by Alfalfa sprouts (2\%) group which was the nearest value to $(-v e)$ control group $(0.332 \pm 0.07) \&(0.29 \pm 0.02)$ respectively.

Rats that received diets supplemented with fenugreek seeds $(5 \%)$, fenugreek sprouts $(5 \%)$, alfalfa seeds $(2 \%)$ and alfalfa sprouts $(2 \%)$ showed significant decrease $(P<0.05)$ in relative 


\section{Rasha M. Bahnasy, et al}

spleen weight when compared with (+ve) control group. The best result was recorded by Fenugreek sprouts $(5 \%)$ group and was the nearest value to $(-v e)$ control group $(0.35 \pm 0.11) \&(0.26 \pm 0.03)$ respectively. Rats which received diets supplemented with Fenugreek seeds (5\%), Fenugreek sprouts $(5 \%)$, Alfalfa seeds $(2 \%)$ and Alfalfa sprouts $(2 \%)$ showed significant decrease $(\mathrm{P}<0.05)$ in relative kidney weight when compared with (+ve) control group. The best result was recorded by Alfalfa sprouts $(2 \%)$ group and was the nearest value to $(-v e)$ control group $(0.74 \pm 0.08) \&(0.64 \pm 0.05)$ respectively.

These results are in agreement with(Ibrahim et al., 2012)who reported that the relative weights of the four examined organs (liver, kidneys, heart, and spleen) were affected by lead acetate ingestion The detected elevation in the organs' weight or ratio is thought to be due to the necrosis and apoptosis and could be attributed to the accumulation of the lipids in the four organs. (Martínez et al., 2016)showed that, Alfalfa intake managed to reduce both liver weight and total fat content, possibly due to its phenolic compounds that may have inhibited the early stages of hepatic steatosis, increasing hepatic $\beta$-oxidation and decreasing adipogenesis or lipogenesis.

Table (2):

Effect of Fenugreek and Alfalfa seeds on relative organs weight in hepatic intoxicated rats.

\begin{tabular}{l|c|c|c|c}
\hline Groups & Larameters & Heart & Spleen & Kidneys \\
\hline (-ve ) Control & $2.69^{\mathrm{c}} \pm 0.311$ & $0.29^{\mathrm{b}} \pm 0.02$ & $0.26^{\mathrm{c}} \pm 0.03$ & $0.64^{\mathrm{c}} \pm 0.05$ \\
\hline (+ve ) Control & $4.66^{\mathrm{a}} \pm 0.15$ & $1.06^{\mathrm{a}} \pm 0.45$ & $1.19^{\mathrm{a}} \pm 0.28$ & $1.54^{\mathrm{a}} \pm 0.37$ \\
\hline Fenugreek seeds 5\% & $2.96^{\mathrm{bc}} \pm 0.12$ & $0.33^{\mathrm{b}} \pm 0.01$ & $0.68^{\mathrm{b}} \pm 0.03$ & $0.77^{\mathrm{c}} \pm 0.13$ \\
\hline Fenugreek sprouts5\% & $2.69^{\mathrm{c}} \pm 0.20$ & $0.44^{\mathrm{b}} \pm 0.19$ & $0.35^{\mathrm{c}} \pm 0.11$ & $0.89^{\mathrm{bc}} \pm 0.23$ \\
\hline Alfalfa seeds 2\% & $3.06^{\mathrm{b}} \pm 0.085$ & $0.94^{\mathrm{a}} \pm 0.37$ & $0.65^{\mathrm{b}} \pm 0.22$ & $1.17^{\mathrm{b}} \pm 0.3 .4$ \\
\hline Alfalfa sprouts 2\% & $2.70^{\mathrm{c}} \pm 0.291$ & $0.332^{\mathrm{b}} \pm 0.07$ & $0.40^{\mathrm{c}} \pm 0.18$ & $0.74^{\mathrm{c}} \pm 0.08$ \\
\hline
\end{tabular}

Effect of Fenugreek and Alfalfa seeds on serum AST, ALT and ALP for hepatic intoxicated rats.

As shown in table (3) results for serum AST, ALT and ALP recorded significant increase for the (+ve) control group when compared to (-ve) control group. All treated groups showed significant decrease $(P<0.05)$ when compared with $(+v e)$ control group.Better results were found in alfalfa sprouts $(2 \%)$ group, fenugreek seeds (5\%) group and fenugreek sprouts $(5 \%)$ group that recorded no significant difference compared to (-ve) control group.

Sivaprasad et al., (2003) demonstrated similar results, that lead changes the liver functions because of inducing fatty liver hence an increase of AST, ALT and ALP levels.On the other hand the findings of this work are in agreement with (Kaviarasan and Anuradha, 2007)whoconcluded the hepatoprotective effect of fenugreek seed polyphenolic extract (FPEt) against ethanol-induced hepatic injury and apoptosis in rats. Treatment with FPEt restored the levels of markers of liver injury and mitigated the alterations in alcohol metabolizing and detoxification enzymes.Also, the results are in agreement with (Anwar et al., 2011) who concluded that treatment with an alcoholic extract of fenugreek seeds significantly decreased serum AST, and ALT levels in diabetic liver.(Ahmad et al., 2013) observed that treatment of rats with low, as well as high, dose of ethanolic extract of $M$. sativa had no adverse effects on the kidney or the liver functions. According to (Annie et al., 2006) phytoestrogens can be used in the treatment of various liver disorders. Also the results agreed with (Martínez et al., 2016) who found that impaired hepatic function involves an increase in the plasma AST, ALT, Y-GT and ALP activities, which was observed in the spontaneously hypertensive rats (SHR) 


\section{Egypt. J. of Nutrition and Health Vol. 15 No. 1 January (2020)}

model. The intake of alfalfa in these animals returned $\mathrm{Y}$-GT and ALP activities to values close to those found in Wistar-Kyoto rats (WKY) animals. Similar findings were described by (AI-Dosari, 2012), who found that alfalfa prevented the increase of ALP activity in serum of $\mathrm{CCl}_{4}$-treated rats. Moreover, the results are in agreement with(Servatyari et al., 2017) who showed that use of the Medicago sativa extract decreased significantly the serum levels of ALP and ALT and in the experimental groups, compared to the control group.

Table(3):

Effect of Fenugreek and Alfalfa seeds on serum AST, ALT and AL Pin hepatic intoxicated rats

\begin{tabular}{l|c|c|c}
\hline \multicolumn{1}{|c|}{ Garameters } & AST (U/L) & ALT (U/L) & ALP (U/L) \\
\hline (-ve ) Control & $72.20^{\mathrm{c}} \pm 3.49$ & $83.8^{\mathrm{c}} \pm 3.96$ & $185.6^{\mathrm{d}} \pm 4.03$ \\
\hline (+ve ) Control & $149.60^{\mathrm{a}} \pm 7.70$ & $171.40^{\mathrm{a}} \pm 7.40$ & $241.2^{\mathrm{a}} \pm 2.58$ \\
\hline Fenugreek seeds 5\% & $81.40^{\mathrm{b}} \pm 6.02$ & $84.20^{\mathrm{c}} \pm 3.70$ & $205.6^{\mathrm{c}} \pm 6.96$ \\
\hline Fenugreek sprouts5\% & $80.60^{\mathrm{b}} \pm 7.12$ & $95.40^{\mathrm{b}} \pm 2.70$ & $189.20^{\mathrm{d}} \pm 4.76$ \\
\hline Alfalfa seeds 2\%. & $81.80^{\mathrm{b}} \pm 1.30$ & $91.00^{\mathrm{b}} \pm 2.5$ & $218.0^{\mathrm{b}} \pm 5.70$ \\
\hline Alfalfa sprouts 2\% & $77.40^{\mathrm{bc}} \pm 3.78$ & $90.6^{\mathrm{b}} \pm 1.67$ & $209^{\mathrm{c}} \pm 3.93$ \\
\hline
\end{tabular}

Effect of Fenugreek and Alfalfa seeds on total protein, albumin and globulin of hepatic intoxicate rats.

Data presented in table (4) showed total protein $(\mathrm{g} / \mathrm{dl})$ albumin and globulin recorded significant decrease for (+ve) control group when compared with the (-ve) control group. Rats received diets supplemented with Fenugreek seeds (5\%), fenugreek sprouts $(5 \%)$, alfalfa seeds $(2 \%)$ and alfalfa sprouts showed significant increase $(\mathrm{P}<0.05)$ in total protein, albumin and globulin when compared with (+ve) control group, with no significant difference among all treated groups. Better resultswere obtained on feeding rats fenugreek seeds (5\%) and alfalfa seeds (2\%). (Sivaprasad et al., 2003)have demonstrated similar results, that lead caused fatty liver and changes the liver functions, that results in decreased albumin/globulin ratio.Serum total proteins were higher in rats treated with high dose of ethanolic extract of $M$. sativa, while no such increase was seen with low dose when compared with the control group (Ahmad et al., 2013). Also the results agreed with(Servatyari et al., 2017) who showed that use of alfalfa increased total protein and fibrinogen in a dose dependent manner in the experimental groups $(p<0.01, p<0.001)$.

Table (4):

Effect of Fenugreek and Alfalfa seeds on serum proteins in hepatic intoxicated rats.

\begin{tabular}{l|c|c|c}
\hline Groups & Parameters & Alb. $(\mathrm{g} / \mathrm{dl})$ & Glob. $(\mathrm{g} / \mathrm{dl})$ \\
\hline (-ve ) Control & $5.32^{\mathrm{a}} \pm 0.23$ & $3.68^{\mathrm{a}} \pm 0.23$ & $1.64^{\mathrm{a}} \pm 0.11$ \\
\hline (+ve ) Control & $3.6^{\mathrm{c}} \pm 0.35$ & $2.76^{\mathrm{c}} \pm 0.32$ & $0.84^{\mathrm{d}} \pm 0.15$ \\
\hline Fenugreek seeds 5\% & $4.48^{\mathrm{b}} \pm 0.22$ & $3.16^{\mathrm{b}} \pm 0.20$ & $1.32^{\mathrm{b}} \pm 0.13$ \\
\hline Fenugreek prouts5\%. & $4.28^{\mathrm{b}} \pm 0.10$ & $3.00^{\mathrm{bc}} \pm 0.12$ & $1.28^{\mathrm{b}} \pm 0.13$ \\
\hline Alfalfa seeds $\%$. & $4.28^{\mathrm{b}} \pm 0.20$ & $3.20^{\mathrm{b}} \pm 0.22$ & $1.08^{\mathrm{c}} \pm 0.08$ \\
\hline Alfalfa sprouts 2\% & $4.34^{\mathrm{b}} \pm 0.11$ & $3.12^{\mathrm{b}} \pm 0.14$ & $1.22^{\mathrm{bc}} \pm 0.08$ \\
\hline Different superscript letters in the column denote high significant differences $(\mathrm{P}<0.05)$.
\end{tabular}




\section{Rasha M. Bahnasy, et al}

Effect of Fenugreek and Alfalfa seeds on SOD and $\alpha$-GST in hepatic intoxicated rats.

Data presented in table (5) showed that results for SOD (U/L) and $\alpha-G S T(n g / m l)$ recorded significant decrease for (+ve) control group when compared to (-ve) control group. Rats received diets supplemented with fenugreek seeds $(5 \%)$, fenugreek sprouts $(5 \%)$, alfalfa seeds( $2 \%)$ and alfalfa sprouts $(2 \%)$ showed significant increase $(\mathrm{P}<0.05)$ when compared with $(+v e)$ control group . The best result was recorded by Alfalfa sprouts (2\%)group which was the nearest value to (-ve) control group.The results agreed with(Sivaprasad et al., 2003) who reported that rats treated with Lead had lowered activities for catalase, superoxide dismutase, glutathione peroxidase and reduced glutathione. Moreover(Tripathi and Chandra, 2009) reported that Fenugreek extract caused significant reduction in LPO and increase in SOD and GST when used in combination with Momordicacharantia (MC) in alloxan-induced diabetic rats.In addition, (Sushma and Devasena, 2010)studied the role of fenugreek in ameliorating the hepato- and nephro-toxicity induced by cypermethrin in rats. They reported that fenugreek reduce the levels of the antioxidant enzymes, such as SOD, and a-GST, which were found to be increased in the liver and kidneys. Authors postulate mechanism of action might be due to the flavonoids present in fenugreek and their ability to scavenge the free radicals induced by cypermethrin metabolism.Also, (Sharma et al., 2011)reported that Lead exposure induced a significant decrease $(P<0.001)$ SOD and a - GST.(Baquer et al., 2011) mentioned that the fenugreek administration protected the liver and kidney of diabetic rats from alteration of levels of antioxidant enzymes (SOD, GPx, CAT) and attributed by the fact that fenugreek husk is a valuable and effective source of natural antioxidants and natural ingredients.

Findings are in agreement with(EI Kader et al., 2012)who found that the treatment with LA significantly decreased the activities of antioxidant enzymes for SOD content as compared to the control animals $(\mathrm{P}<0.05)$. The result of the present study found that sprouting for fenugreek or alfalfa were more effective than seeds. This result agreed with (Moradi kor et al., 2013)who noted that germination or sprouting of fenugreek seeds increased their antioxidant profile.

The findings in this study are in agreement with(Shi et al., 2014)who concluded that the SOD activity in serum, liver, spleen, and muscle increased linearly .liver SOD activity were affected by treatment of alfalfa saponin extract. Also, the results agreed with (Martínez et al., 2016)who found a decreased activity of both SOD and GPx in the liver of SHR, whereas the dietary administration of alfalfa was an efficient strategy to return GPx activity back to values even higher than those of normal animals. This potential has been attributed to different polyphenols and polysaccharides found in alfalfa(Al-Dosari, 2012; Wang et al., 2014) as well as to uronic acid which is capable of inhibiting the formation of hydroxyl and superoxide radicals(Chen et al., 2004).

Table (5):

Effect of Fenugreek and Alfalfa seeds on SOD and $\alpha$-GST in hepatic intoxicated rats.

\begin{tabular}{l|c|c}
\hline Groups & Parameters & SOD (U/L) \\
\hline (-ve ) Control & $0.305^{\mathrm{a}} \pm 0.0005$ & $0.457^{\mathrm{a}} \pm 0.003$ \\
\hline (+ve ) Control & $0.087^{\mathrm{f}} \pm 0.003$ & $0.108^{\mathrm{f}} \pm 0.001$ \\
\hline Fenugreek seeds 5\% & $0.113^{\mathrm{e}} \pm 0.0025$ & $0.128^{\mathrm{e}} \pm 0.001$ \\
\hline Fenugreek sprouts5\%. & $0.176^{\mathrm{d}} \pm 0.003$ & $0.195^{\mathrm{d}} \pm 0.002$ \\
\hline Alfalfa seeds 2\%. & $0.213^{\mathrm{c}} \pm 0.001$ & $0.262^{\mathrm{c}} \pm 0.002$ \\
\hline Alfalfa sprouts 2\% & $0.229^{\mathrm{b}} \pm 0.0005$ & $0.305^{\mathrm{b}} \pm 0.001$ \\
\hline \multicolumn{2}{c|}{ Different superscript letters in the column denote high significant differences (P<0.05). }
\end{tabular}




\section{Egypt. J. of Nutrition and Health Vol. 15 No. 1 January (2020)}

\section{Effect of Fenugreek and Alfalfa seeds on MAO and LEAD in hepatic intoxicated rats}

Data presented in table (6) showed that serum MAO $(\mathrm{mu} / \mathrm{ml})$ recorded significant decrease for (+ve) control group when compared with the (-ve) control group. Rats that received diets supplemented with Fenugreek seeds (5\%), Fenugreek sprouts(5\%), Alfalfa seeds (2\%) and Alfalfa sprouts( $2 \%$ ) showed significant increase $(\mathrm{P}<0.05)$ when compared with the $(+v e)$ control group. The best result was recorded by Alfalfa sprouts (2\%) group which was the nearest value to (-ve) control group.

Results for lead (mcq/l) recorded significant increase for (+ve) control group when compared to the (-ve) control group. Rats that received diets supplemented with Fenugreek seeds $(5 \%)$, Fenugreek sprouts (5\%), Alfalfa seeds(2\%) and Alfalfa sprouts $(2 \%)$ showed significant decrease $(\mathrm{P}<0.05)$ when compared with $(+\mathrm{ve})$ control group. The best result was found in Alfalfa sprouts (2\%)group which was the nearest value to (-ve) control group. (Haleagrahara et al., 2011) showed a significant increase in blood and bone marrow lead levels following the consumption of lead acetate in drinking water for 21 days. Lead acetate absorbed from the gastrointestinal tract is carried via blood, mainly in the erythrocytes, to the bone where it accumulates.Also,the results agreed with(EI Kader et al., 2012) where Lead concentration was significantly $(P<0.01)$ increased in rats treated with $L A$ alone for 7 days comparing with the control rats. (Devi et al., 2005) found that on giving young and adult rats $\mathrm{Pb}$ in water, they reposted the activity of the enzyme MAO and other catecholamine in the brain, they concluded $\mathrm{Pb}$ - exposure perturbs the aminergic system in the cerebral cortex, cerebellum and hippocampus and may contribute to the cognitive and behavioral impairments observed in $\mathrm{Pb}$-exposed rats.

Table(6):

Effect of Fenugreek and Alfalfa seeds on MAO and Lead in hepatic intoxicated rats

\begin{tabular}{|c|c|c|}
\hline $\begin{array}{ll}\text { Groups } & \text { Parameters } \\
\end{array}$ & $\mathrm{MAO}(\mathrm{mu} / \mathrm{ml})$ & Lead(mcq/l) \\
\hline (-ve ) Control & $0.29^{\mathrm{a}} \pm 0.001$ & $70.97^{\dagger} \pm 0.44$ \\
\hline (+ve ) Control & $0.118^{f} \pm 0.001$ & $211.37^{\mathrm{a}} \pm 3.2$ \\
\hline Fenugreek seeds $5 \%$ & $0.12^{e} \pm 0.001$ & $171.17^{b} \pm 4.1$ \\
\hline Fenugreek sprouts5\%. & $0.185^{d} \pm 0.001$ & $122.74^{d} \pm 0.48$ \\
\hline Alfalfa seeds $2 \%$. & $0.237^{\mathrm{c}} \pm 0.001$ & $133.78^{\mathrm{C}} \pm 0.28$ \\
\hline Alfalfa sprouts $2 \%$ & $0.261^{b} \pm 0.001$ & $111.54^{\mathrm{e}} \pm 1.1$ \\
\hline
\end{tabular}

\section{Conclusion}

According to these findings It could be concluded that Fenugreek seeds, Fenugreek sprouts, Alfalfa seeds and Alfalfa sprouts are considered as a potential source of natural antioxidant with hepatoprotective activity. The hepatoprotective effect of seeds and their sprouts of the above mentioned may be attributed to phenolic compounds, which is known for their antioxidant activity. Further detailed investigations on these seeds are needed in order to identify and isolate the hepatoprotective components in these seeds and to justify their use in the treatment of liver disorders. The authors recommend the public education to increase awareness of the potential toxic effects of lead polution . 


\section{Rasha M. Bahnasy, et al}

\section{References}

Abbruscato, Pamela, Tosi, Solveig, Crispino, Laura, Biazzi, Elisa, Menin, Barbara, Picco, Anna M, Tava, Aldo. (2014).

Triterpenoid glycosides from medicago sativa as antifungal agents against Pyricularia oryzae. Journal of agricultural and food chemistry, 62(46), 11030-11036.

Acharya, SN, Thomas, JE, \& Basu, SK. (2008).

Fenugreek, an alternative crop for semiarid regions of North America. Crop science, 48(3), 841-853.

Ahmad, Nazir, Zia-Ur-Rahman, Nazir;, Akhtar, Nafees, Ali, Shujait, Ahmad, Maqbool, \& Ahmad, ljaz. (2013).

Effects of Medicago sativa on Some Serum Biochemical Metabolites in Rats. International Journal of Agriculture \& Biology, 15(2).p297-300.

Al-Dosari, Mohammed S. (2012).

In vitro and in vivo antioxidant activity of alfalfa (Medicago sativa L.) on carbon tetrachloride intoxicated rats. The American journal of Chinese medicine, 40(04), 779-793.

Annie, Shirwaikar, Prabhu, RG, \& Malini, S. (2006).

Activity of Wedelia calendulacea Less. in post-menopausal osteoporosis. Phytomedicine, 13(1-2), 43-48.

Anwar, Sirajudheen, Desai, Sandhya, Eidi, Maryam, \& Eidi, Akram. (2011).

Chapter 56 - Antidiabetic Activities of Fenugreek (Trigonella foenum-graecum) Seeds A2 Preedy, Victor R. In R. R. Watson \& V. B. Patel (Eds.), Nuts and Seeds in Health and Disease Prevention (pp. 469-478). San Diego: Academic Press.

Baquer, Najma Zaheer, Kumar, Pardeep, Taha, Asia, Kale, RK, Cowsik, SM, \& McLean, P. (2011). Metabolic and molecular action of Trigonella foenum-graecum (fenugreek) and trace metals in experimental diabetic tissues. Journal of Biosciences, 36(2), 383-396.

Bilandžić, Nina, Sedak, Marija, Vratarić, Darija, Perić, Tomislav, \& Šimić, Branimir. (2009). Lead and cadmium in red deer and wild boar from different hunting grounds in Croatia. Science of the total environment, 407(14), 4243-4247.

Board, N. ( 2010).

Hand book on spices. Asia Pacific Business Press Inc, Delhi. 137-138.

Bora, Kundan Singh, \& Sharma, Anupam. (2011).

Phytochemical and pharmacological potential of Medicago sativa: a review. Pharmaceutical biology, 49(2), 211-220. 


\section{Egypt. J. of Nutrition and Health Vol. 15 No. 1 January (2020)}

Chapman, DG, Castillo, Raul, \& Campbell, JA. (1959).

Evaluation of protein in foods: 1. A method for the determination of protein efficiency ratios. Canadian Journal of Biochemistry and Physiology, 37(5), 679-686.

Chary, TM, \& Sharma, Hariom. (2004).

Practical biochemistry for medical and dental students: JAYPEE BROTHERS PUBLISHERS.

Chen, Haixia, Zhang, Min, \& Xie, Bijun. (2004).

Quantification of uronic acids in tea polysaccharide conjugates and their antioxidant properties. Journal of Agricultural and Food Chemistry, 52(11), 3333-3336.

Chen , Lei, Liu, Jie, Zhang, Yaqiong, Niu, Yuge, Dai, Bona, \& Yu, Liangli. (2015).

A novel alkaline hemicellulosic heteroxylan isolated from alfalfa (Medicago sativa L.) stem and its thermal and anti-inflammatory properties. Journal of agricultural and food chemistry, 63(11), 2970-2978.

Chevassus, Hugues, Gaillard, Jean-Baptiste, Farret, Anne, Costa, Françoise, Gabillaud, Isabelle, Mas, Emilie, ... Renard, Eric. (2010).

A fenugreek seed extract selectively reduces spontaneous fat intake in overweight subjects. European journal of clinical pharmacology, 66(5), 449-455.

Courtois, Elise, Marques, Maria, Barrientos, Alberto, Casado, Santos, \& López-Farré, Antonio. (2003).

Lead-induced down regulation of soluble guanylate cyclase in isolated rat aortic segments mediated by reactive oxygen species and cyclooxygenase-2. Journal of the American Society of Nephrology, 14(6), 1464-1470.

Devi, CB, Reddy, GH, Prasanthi, RPJ, Chetty, CS, \& Reddy, GR. (2005).

Developmental lead exposure alters mitochondrial monoamine oxidase and synaptosomal catecholamine levels in rat brain. International journal of developmental neuroscience, 23(4), 375-381.

Doherty, Richard E. (2000).

A history of the production and use of carbon tetrachloride, tetrachloroethylene, trichloroethylene and 1, 1, 1-trichloroethane in the United States: Part 1--historical background; carbon tetrachloride and tetrachloroethylene. Environmental forensics, 1(2), 6981.

Drupt, F. (1974).

Colorimetric method for determination of albumin. Phar. Bio, 9, 777.

Ehsanpour, Ali Akbar, \& Razavizadeh, Roya. (2005).

Effect of UV-C on drought tolerance of alfalfa (Medicago sativa) callus. American Journal of Biochemistry and Biotechnology, 1(2), 107-110. 


\section{Rasha M. Bahnasy, et al}

El-Nekeety, Aziza A., El-Kady, Ahmed A., Soliman, Mahmoud S., Hassan, Nabila S., \& AbdelWahhab, Mosaad A. (2009).

Protective effect of Aquilegia vulgaris (L.) against lead acetate-induced oxidative stress in rats. Food and Chemical Toxicology, 47(9), 2209-2215. doi: https://doi.org/10.1016/j.fct.2009.06.019

El Kader, MA Abd, El-Sammad, NM, \& Hamdy, T. (2012).

The protective role of rosemary (Rosmarinus officinalis) in lead acetate induced toxicity in rats. Journal of Applied Sciences Research, 8(6), 3071-3082.

Ezejindu, DN, Chinweife, KC, \& Ihentuge, CJ. (2013).

The Effects of Moringa Extract On Liver Enzymes Of Carbon Tetrachloride Induced Hepatotoxicity In Adult Wister Rats. Int J Eng Sci, 2, 54-59. Gatouillat, Grégory, Alabdul Magid, Abdulmagid, Bertin, Eric, Okiemy-Akeli, Marie-Genevieve, Morjani,

Hamid, Lavaud, Catherine, \& Madoulet, Claudie. (2014).

Cytotoxicity and apoptosis induced by alfalfa (Medicago sativa) leaf extracts in sensitive and multidrug-resistant tumor cells. Nutrition and cancer, 66(3), 483-491.

Geetha, M, Suneel , KR, Krupanidhi , AM, Muralikrishna , K S, Avin , A P , \& Prashanth , P. (2011).

Effect of Fenugreek on Total Body and Organ Weights: A Study on Mice. Pharmacology online ;3:747-752.

Gupta, LM, \& Raina, R. (1998).

Side effects of some medicinal plants. Current Science, 75(9), 897-900.

Habig, William H, Pabst, Michael J, \& Jakoby, William B. (1974).

Glutathione S-transferases the first enzymatic step in mercapturic acid formation. Journal of biological Chemistry, 249(22), 7130-7139.

Haleagrahara, Nagaraja, Chakravarthi, Srikumar, Kulur, Anupama Bangra, \& Radhakrishnan, Ammu. (2011).

Effects of chronic lead acetate exposure on bone marrow lipid peroxidation and antioxidant enzyme activities in rats. African Journal of Pharmacy and Pharmacology, 5(7), 923-929.

Holt, Andrew, Sharman, Dennis F., Baker, Glen B., \& Palcic, Monica M. (1997).

A Continuous Spectrophotometric Assay for Monoamine Oxidase and Related Enzymes in Tissue Homogenates . Analytical Biochemistry, 244(2), 384-392 . Doi :

https://doi.org/10.1006/abio.1996.9911

Horne, S, H (2013).

Natural remedies for common health conditions: A guide to herbs and supplement for specific heath problems. Available online at: www.treelite.com/downloads/Natural- Remedies.pdf.

Hwang, DF, \& Wang, LC. (2001).

Effect of taurine on toxicity of cadmium in rats. Toxicology, 167(3), 173-180. 


\section{Egypt. J. of Nutrition and Health Vol. 15 No. 1 January (2020)}

Ibrahim, Nabil M, Eweis, Esam A, El-Beltagi, Hossam Saad, \& Abdel-Mobdy, Yasmin E. (2011). RETRACTED ARTICLE: The Effect of Lead Acetate Toxicity on Experimental Male Albino Rat. Biological trace element research, 144(1-3), 1120-1132.

Ibrahim, Nabil M, Eweis, Esam A, El-Beltagi, Hossam S, \& Abdel-Mobdy, Yasmin E. (2012). Effect of lead acetate toxicity on experimental male albino rat. Asian Pacific journal of tropical biomedicine, 2(1), 41-46.

Kaviarasan, Subramanian, \& Anuradha, CV. (2007).

Fenugreek (Trigonella foenum graecum) seed polyphenols protect liver from alcohol toxicity: a role on hepatic detoxification system and apoptosis. Die Pharmazie-An International Journal of Pharmaceutical Sciences, 62(4), 299-304.

Khan, MSH, Mostofa, M, Jahan, MS, Sayed, MA, \& Hossain, MA. (2008).

Effect of garlic and vitamin B-complex in lead acetate induced toxicities in mice. Bangladesh Journal of Veterinary Medicine, 6(2), 203-210.

Khole, Swati, Chatterjee, Suchandra, Variyar, Prasad, Sharma, Arun, Devasagayam, TPA, \& Ghaskadbi, Saroj. (2014).

Bioactive constituents of germinated fenugreek seeds with strong antioxidant potential. Journal of functional foods, 6, 270-279.

Ma, Qin-Ge, Li, Ting, Wei, Rong-Rui, Liu, Wen-Min, Sang, Zhi-Pei, \& Song, Zhong-Wen. (2016). Characterization of chalcones from Medicago sativa L. and their hypolipidemic and antiangiogenic activities. Journal of agricultural and food chemistry, 64(43), 8138-8145.

Mahan, L Kathleen, \& Escott-Stump, Sylvia. (2008).

Krause's Food \& Nutrition Therapy, 12th ed., Saunders- Elsevier, New York, pp:709-710.

Markowitz , M. (2000).

Lead Poisoning. Pediatrics in Review, (21):327-335.

Martínez, Rosario, Kapravelou, Garyfallia, Porres, Jesús M, Melesio, Adela M, Heras, Leticia, Cantarero, Samuel, . . . López-Jurado, María. (2016).

Medicago sativa L., a functional food to relieve hypertension and metabolic disorders in a spontaneously hypertensive rat model. Journal of Functional Foods, 26, 470-484.

Misra, Hara P, \& Fridovich, Irwin. (1972).

The role of superoxide anion in the autoxidation of epinephrine and a simple assay for superoxide dismutase. Journal of Biological chemistry, 247(10), 3170-3175.

Moradi kor, Nasroallah, Mohamad, Bagher, Didarshetaban, Hamid, Reza \& Saeid, Pour. (2013). Fenugreek (Trigonella foenum-graecum L.) as a valuable medicinal plant. International Journal of Advanced Biological and Biomedical Research, 1(8), 922-931. 


\section{Rasha M. Bahnasy, et al}

Murlidhar, Meghwal, \& Goswami, TK. (2012).

A review on the functional properties, nutritional content, medicinal utilization and potential application of fenugreek. Journal of Food Processing and Technology, 3(9), 1-10.

Obizoba, Ikemefuna C, \& Atii, JV. (1994).

Evaluation of the effect of processing techniques on the nutrient and antinutrient contents of pearl millet (Pennisetum glaucum) seeds. Plant Foods for Human Nutrition, 45(1), 23-34.

Rafińska, Katarzyna, Pomastowski, Paweł, Wrona, Olga, Górecki, Ryszard, \& Buszewski, Bogusław. (2017).

Medicago sativa as a source of secondary metabolites for agriculture and pharmaceutical industry. Phytochemistry Letters, 20, 520-539.

Raju, Jayadev, Gupta, Dhananjay, Rao, Araga R, Yadava, Pramod K, \& Baquer, Najma Z. (2001). Trigonella foenum graecum (fenugreek) seed powder improves glucose homeostasis in alloxan diabetic rat tissues by reversing the altered glycolytic, gluconeogenic and lipogenic enzymes. Molecular and cellular biochemistry, 224(1-2), 45-51.

Reitman, Stanley, \& Frankel, Sam. (1957).

A colorimetric method for the determination of serum glutamic oxalacetic and glutamic pyruvic transaminases. American journal of clinical pathology, 28(1), 56-63.

Roy, AV. (1970).

Rapid method for determining alkaline phosphatase activity in serum with thymolphthalein monophosphate. Clinical chemistry, 16(5), 431-436.

Schermer, Siegmund. (1967).

Blood morphology of laboratory animals.

Seddik, L, Bah, TM, Aoues, A, Brnderdour, M, \& Silmani, M. (2010).

Dried leaf extract protects against lead-induced neurotoxicity in Wistar rats. Eur $J$ Sci Res, 42(1), 139-151.

Servatyari, Karo, Ahmadi, Abbas, Kashefi, Hajar, Manbari, Mohammad Nazir, Rostami, Amin, \& Moulodi, Mohammad Raman. (2017).

The effect of hydroalcoholic extract of Medicago sativa on liver function tests, blood biochemical factors and coagulation system in male rats. Scientific Journal of Kurdistan University of Medical Sciences, 21(6), 16-26.

Sharifi, Ali M, Baniasadi, Shadi, Jorjani, Masoomeh, Rahimi, Farzaneh, \& Bakhshayesh, Masoomeh. (2002).

Investigation of acute lead poisoning on apoptosis in rat hippocampus in vivo. Neuroscience letters, 329(1), 45-48.

Sharma, Veena, Sharma, Sadhana, \& Pracheta, Sharma SH. (2011).

Lead induced hepatotoxicity in male swiss albino mice: the protective potential of the hydromethanolic extract of Withania somnifera. Int. J. Pharmaceu. Sci. Rev. Res, 7, 116-121. 


\section{Egypt. J. of Nutrition and Health Vol. 15 No. 1 January (2020)}

Shi, YH, Wang, J, Guo, R, Wang, CZ, Yan, XB, Xu, B, \& Zhang, DQ. (2014).

Effects of alfalfa saponin extract on growth performance and some antioxidant indices of weaned piglets. Livestock Science, 167, 257-262.

Sivaprasad, R, Nagaraj, M, \& Varalakshmi, P. (2003).

Combined efficacies of lipoic acid and meso-2, 3-dimercaptosuccinic acid on lead-induced erythrocyte membrane lipid peroxidation and antioxidant status in rats. Human \& experimental toxicology, 22(4), 183-192.

Sivaprasad, R, Nagaraj, M, \& Varalakshmi, P. (2004).

Combined efficacies of lipoic acid and 2, 3-dimercaptosuccinic acid against lead-induced lipid peroxidation in rat liver. The Journal of nutritional biochemistry, 15(1), 18-23.

Snedecor, GW, \& Cochran, WG. (1979).

Design and analysis of sampling. Statistical Methods. GW Snedecor and WG Cochran, ed. The lowa State University Press, Ames, 504-539.

Sonnenwirth, Alex C, \& Jarett, Leonard. (1980).

Gradwohl's clinical laboratory methods and diagnosis: Mosby.

Spencer, K., \& Price, C.P. (1977).

Determination of serum albumin. Ann. Clin. Biochem.14:105

Sushma, Navayath, \& Devasena, Thiyagarajan. (2010).

Aqueous extract of Trigonella foenum graecum (fenugreek) prevents cypermethrin-induced hepatotoxicity and nephrotoxicity. Human \& experimental toxicology, 29(4), 311-319.

Tripathi, Uma Nath, \& Chandra, Deepak. (2009).

The plant extracts of Momordica charantia and Trigonella foenum graecum have antioxidant and anti-hyperglycemic properties for cardiac tissue during diabetes mellitus. Oxidative Medicine and Cellular Longevity, 2(5), 290-296.

Villeda-Hernandez, J, Barroso-Moguel, R, Mendez-Armenta, M, Nava-Ruız, C, Huerta-Romero, R, \& Rıos, C. (2001).

Enhanced brain regional lipid peroxidation in developing rats exposed to low level lead acetate. Brain research bulletin, 55(2), 247-251.

Vuorela, P, Leinonen, Maija, Saikku, Pekka, Tammela, P, Rauha, J-P, Wennberg, T, \& Vuorela, H. (2004).

Natural products in the process of finding new drug candidates. Current medicinal chemistry, 11(11), 1375-1389.

Wang, Shaopu, Dong, Xiaofang, Ma, Hao, Cui, Yaoming, \& Tong, Jianming. (2014).

Purification, characterisation and protective effects of polysaccharides from alfalfa on hepatocytes. Carbohydrate polymers, 112, 608-614. 
Rasha M. Bahnasy, et al

التأثير الوقائي لبذور وبراعم الحلبة والبرسيم الحجازي على الجرذان المعرضة

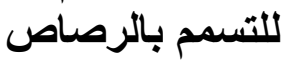

رشا عحم بهنسي ، ايمان السيد عبد الهادي ، مي حسين عبد القتاح

قسم التغذية و علوم الأطعمة- كلية الاقتصاد المنزلي-جامعة الأزهر

المستخلص العزبي

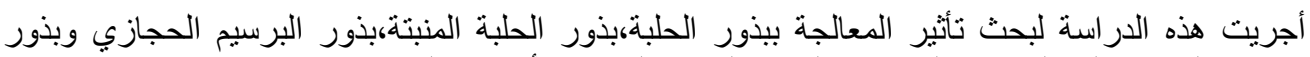

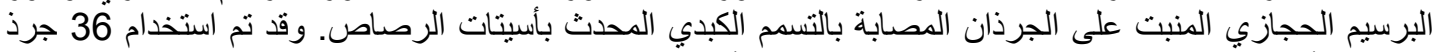

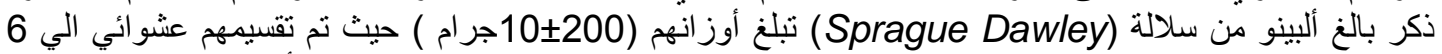

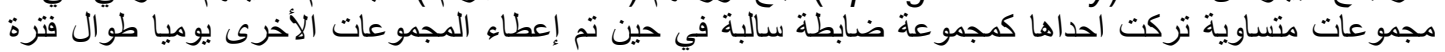

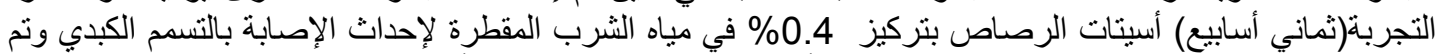

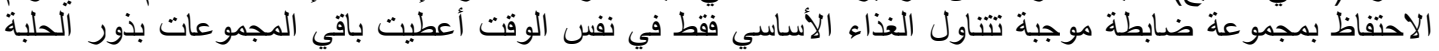

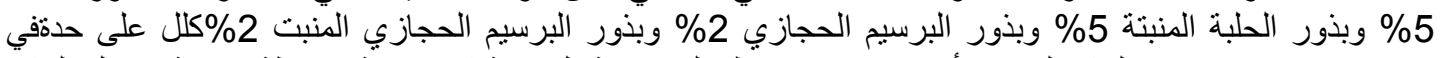

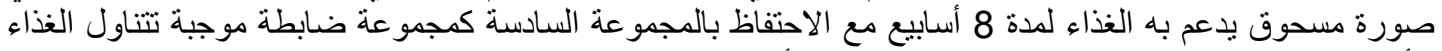

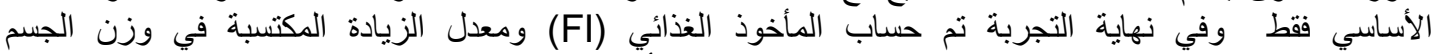

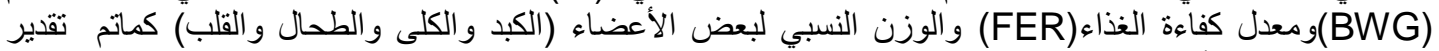

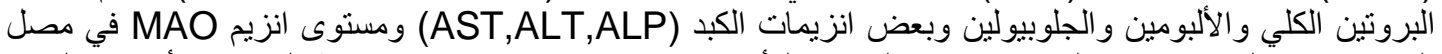

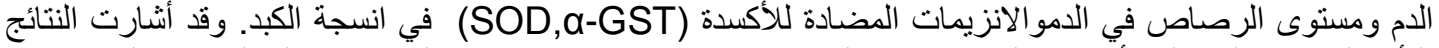

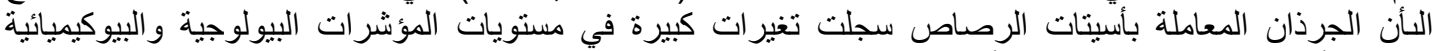

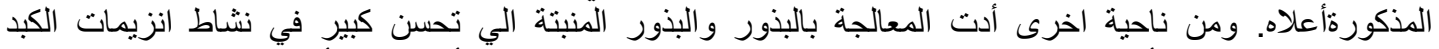

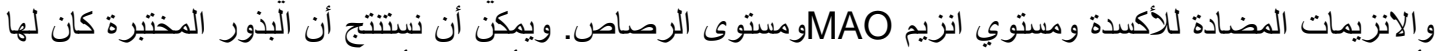

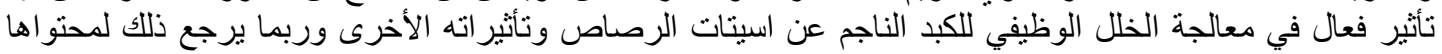
المرتفع من بعض المركبات الفينولية.

الكلمات المفتاحية سمية الكبد سانزيمات الكبد ـ أسيتات الرصاصــ بذور الحلبة ـ بذور الحلبة المنبتة ـ بذور البرسيم الحجازي - بذور البرسيم الحجازي المنبتة - الانزيمات المضادة للأكسدة. 